\title{
Understanding and Confronting Barriers to Youth Voting in America
}

\author{
Jared A. McDonald \\ Ph.D. Candidate \\ Department of Government and Politics \\ University of Maryland \\ Michael J. Hanmer \\ Professor \\ Department of Government and Politics \\ University of Maryland
}

\begin{abstract}
We review the literature on youth voting, paying particular attention to how electoral institutions influence participation. We find that barriers to registration have a disproportionate effect on young people but that their removal alone will not be sufficient to produce large-scale shifts in turnout. Though there are theoretical, empirical, and normative reasons to make voting easier, we argue that electoral reforms designed to promote registration and turnout are best viewed as vehicles to facilitate other efforts aimed at increasing individuals' capacity for and interest in participating. Advocacy groups and scholars alike should devote more attention to identifying ways to engage young people. We recognize the task is a challenging one but we are cautiously optimistic that substantial change is possible.
\end{abstract}

Prepared for the Data-Driven Strategies to Promote Youth Turnout workshop at the Massachusetts Institute of Technology, August 29, 2018. We thank the Mellon Foundation for funding and the University of Michigan and Massachusetts Institute of Technology for hosting. All views and errors are our own and do not represent the funding or supporting organizations. 
"The blunt truth is that politicians and officials are under no compulsion to pay much heed to classes and groups of citizens who do not vote"

-V.O. Key, 1949

\section{The Problem of Low Youth Turnout}

Political scientists have long known that voting provides a key link to substantive representation in America (Pitkin 1967). Scholars have focused on the disparities in substantive representation across racial and ethnic groups (see e.g. Barreto, Segura, and Woods 2004; Rouse 2013; Tate 2003), gender (see e.g. Mansbridge 1999; Mendelberg, Karpowitz, and Goedert 2013; Reingold and Harrell 2010), economic groups (see e.g. Gilens 2012), and age groups (see e.g. Wattenberg 2008). Although scholars have taught us a great deal in each area, we are far from finding reliable ways to reduce the inequalities in participation, and thus representation. This is particularly true with regard to gaps in voting between younger and older citizens. For example, in 2016, a highly contested election with well-known candidates who presented starkly different platforms, the gap in turnout between 18-24-year-olds and those 25 and older was over 20 percentage points. This gap is slightly larger than the turnout gap between these age groups in 1972, the first presidential election in which 18-year-olds could vote.

In this paper, we focus on how structural barriers influence youth participation. In doing so we argue that advocates of participatory democracy should view electoral reforms designed to promote registration and turnout as vehicles to facilitate other efforts aimed at increasing individuals' capacity for and interest in participating. That is, we believe that registration and voting should be easy, but making it easy is far from enough to produce large-scale shifts in 
turnout rates. To be sure, other work has made this point but we add emphasis to it and try to provide clarity on how and why this is the case.

We begin with a review of the literature on what we generally know and don't know about youth turnout. We first discuss socialization, noting the limits to turning what we know into policy changes. Next, we cover barriers to registration and voting. Much of the extant research has not explored whether or how these barriers differentially influence the behavior of young people; but when it does, the evidence suggests young people are especially disadvantaged. This leads us to a discussion of mobilization and motivational factors, which we believe matter most, recognizing that changes in these factors often come at a glacial pace or are difficult to scale. Finally, we make recommendations for future research on this crucial topic. Chief among these areas is research regarding factors that motivate young people to register and vote, as well as the costs young voters face when trying to do so. We argue that many young Americans are interested in getting involved, but they move frequently, meaning that electoral rules disproportionately keep them from participating and they are less likely to be contacted. Moreover, we contend that young people find voting to be a relatively unsatisfying form of participation. Important motivations for voting, such as civic duty, are not particularly high among young people. Instead, young people seek out more expressive activities, such as protesting or contacting elected representatives. A great deal of research exists in some of these areas, but many literatures lack a firm consensus, while in other areas rapidly changing voting laws make new research necessary. 


\section{What We Know About Youth Voting (and What We Don't)}

Looking at the ways in which democracy functions in American society, scholars note that turnout is low (Blais 2000; Lijphart 1997; Rosenstone and Hansen 1993; Verba, Schlozman, and Brady 1995), but especially so among young voters and young voters from minority backgrounds (Dalton 2007; Michelson 2006). While it is true that turnout rates across the lifetime of a cohort follow a curvilinear trend, there are also important differences that exist between generations. Bhatti and Hansen (2011) suggest that the higher rates of voting among pre-baby boom generations foreshadow a drop in voting rates across electorates in both the United States and Western Europe. Because younger generations are less invested in voting, it is supposed that these groups get ignored by politicians who are primarily concerned with their reelection campaigns. This is an issue if young people have policy preferences that differ from older, more politically engaged groups, which the evidence suggests they do (Leighley and Nagler 2013). While we know a great deal about what factors influence voting decisions among young groups, relatively little is known about how we can successfully boost youth turnout rates. Toward a better understanding, and particularly for a better understanding of how institutional factors matter, we provide a brief review of what we do know.

\section{Early Socialization Matters but Interventions Are Limited}

What are the primary factors that influence voting among young people? An extensive literature focuses on early socialization. Parents, schools, and communities shape how young people view political institutions and impact their inclination to engage in political action. The foundational literature for American political behavior focuses on the family unit as the core feature shaping political preferences and instilling a partisan orientation toward political events 
that persist well into later life (Berelson, Lazarsfeld, and McPhee 1954; Campbell et al. 1960). Jennings and Niemi (1974) provide evidence that parents play a central role in the political behavior of their children, especially if that child develops political attachments prior to the time they leave their parents' home. Eric Plutzer (2002) notes that people must first begin their lives as non-voters and then develop the voting habit. Developing this voting habit depends on the ability of a person to overcome informational barriers to voting, so parental resources become critical to a young person who has recently become eligible to vote. David Campbell (2006) argues that the decision of whether or not to vote comes down primarily to internalizing norms. Internalizing norms is dependent on social context, which is why he identifies three primary factors that influence turnout: the community in which one currently resides; the community in which one grew up; and what behaviors one had when younger. The last two factors clearly put the emphasis on early childhood as developing the central habits that determine voting. While "culture" is a term difficult to define in empirical analyses, the culture of one's childhood community nonetheless remains one of the primary factors for the lifelong behavior of any individual.

Together with parenting and local communities, schooling plays a large part in the political socialization process. Civic education, part of the school curricula in all 50 states, is a vital component of this. A number of studies have found that civic education boosts turnout (Gill et al. 2018; Sondheimer and Green 2010; Dee 2004; Milligan et al. 2004; Niemi and Junn 2005; Campbell and Niemi 2016; Tripodo and Pondiscio 2017).

Interestingly, however, Giersch and Dong (2017) do not find that mandating civics classes boosts political engagement, while other scholarship (see e.g. Haste 2010; Gill et al. 2018) argues that civic education may only be useful in particular circumstances. For example, 
Haste (2010) argues that civics classes must move beyond simply teaching to a test and must instead engage students in meaningful political discussion about the real world and community involvement. Similarly, Gill and colleagues (2018) examine the impact of a particular charter school (Democracy Prep), which fosters civic education through participation in public meetings, meeting individually with local legislators, as well as debating and discussing political essays with classmates. The randomized nature of their study provides convincing evidence that schools, when equipped with the right tools, can foster a greater sense of civic responsibility among students. Additionally, Campbell and Niemi (2016) find that state-level civics exams are modestly successful in boosting civic knowledge, but that the effects are highest when the exams are a requirement for high school graduation and are particularly strong among people with less previous exposure to information on American politics, such as the children of recent immigrants.

This line of research supports what Benenson, Brower, and Thomas (2016) argue, which is that young people do not suffer from apathy. Instead, they argue that schools and other political institutions are doing a poor job of promoting political engagement. Colleges, in particular, they reason, do not do enough to promote diversity, tackle controversial issues, and teach community engagement.

Reviewing the literature on political socialization, it is clear that one's teen years are critical, in large part because voting decisions are habit forming and therefore set the pattern for later life. When someone makes the decision to vote for the first time, they become far more likely to engage in future elections (Gerber, Green, and Shachar 2003). While the above shows we have learned a great deal, there are fairly obvious limits when it comes to translating this knowledge into practical ways to increase turnout. We won't begin to speculate about how we 
might make parents or communities into better civics instructors. In our most at-risk communities, there are issues far more pressing with which to contend.

The path to political socialization through schools is promising but still daunting. The American education system is fragmented, so any innovation on civic education is hard to implement on a national level. While all 50 states require students to complete some form of civic education, 37 require students to demonstrate a proficiency in civics and 17 include civic learning as part of an accountability framework for public schools. ${ }^{1}$ But even with national or state level commitment, implementation on the ground is sure to vary. The most well off schools will be in the best position to implement new programs and their students will be in the best position to be responsive, likely leading to an exacerbation of existing inequalities. Additionally, given the fears expressed by many politicians regarding "indoctrination" through nationalized education standards, any effort to implement wholesale changes will undoubtedly face resistance. ${ }^{2}$ This isn't to say that this is a dead end, but reformers have to take serious account of a number of harsh realities.

\section{Electoral Institutions Matter, At Least Somewhat, And Are Malleable}

Prompted by the problem of low and unequal turnout that Lijphart (1997) skillfully describes, scholars have devoted significant attention to the ways in which electoral institutions influence participation. Given that much of this work focuses on the U.S. it is no surprise to those familiar with the history of voting rights in the U.S. that most of this research comes from the perspective of removing various barriers to participation.

\footnotetext{
${ }^{1}$ Education Commission of the States, "50-State Comparison: Civic Education Policies."

${ }^{2}$ For example, Education Secretary Betsy Devos has warned that American colleges too often tell students "what to do, what to say, and more ominously, what to think."
} 
The United States has one of the most complicated set of rules for voting in any western democracy (e.g. Powell 1986). A central feature of this system is that the responsibility for voter registration has traditionally been placed on the individual rather than government. ${ }^{3}$ Another important feature is decentralization - while each state must meet certain requirements, they are still charged with administering elections. As a result, residents of each state face a different set of rules and processes. Included among the differences is the extent to which local jurisdictions have control over the voting process. As we discuss below, this has important implications for all, and young people in particular. We now turn to an examination of what we know about the effects of various electoral laws on turnout. This research has largely relied on rational choice theory (Downs 1957; Riker and Ordeshook 1968), predicting that lowering the costs of voting should increase the probability that an individual will vote. Our focus is on voter registration laws and so-called convenience reforms designed to make voting easier for those who are already registered, but we also discuss voter identification laws and various laws that relate to the access to polling locations.

\section{Voter Registration}

The earliest systematic research on voter registration traces back to Gosnell (1927) and was revitalized by Wolfinger and Rosenstone's (1980) seminal work. Wolfinger and Rosenstone's (1980) results using data from 1972 suggested that allowing election day registration (EDR) could increase turnout by about 6 percentage points with the largest effects among those least likely to vote, including young people. Their work generated debate about the overall effect size (e.g. Hanmer 2009) and especially with regard to for whom the effects would be largest (Brians and Grofman 1999; Hanmer 2009; Huang and Shields 2000; Highton 1997;

\footnotetext{
${ }^{3}$ As we discuss later, automatic registration represents a massive change in the approach to voting in the U.S.
} 
Knack and White 2000; Leighley and Nagler 2013; Mitchell and Wlezien 1995; Nagler 1991, 1994; Teixeira 1992). The focus of the debate was on effects across levels of educational attainment but researchers often reported results by age as well.

Using a difference-in-difference approach and recognizing that state laws are not exogenous, Hanmer (2009) reports results that are generally more modest in size and, contrary to expectations from the previous literature, do not extend to states that adopted EDR as a means to avoid the National Voter Registration Act of 1993 (NVRA, aka motor voter). ${ }^{4}$ Although the effects are smaller, like Wolfinger and Rosenstone (1980), Hanmer (2009) finds that young people would benefit the most from EDR. However, he also notes that the extra boost young people would see is small and would do little to reduce the gap in turnout among younger and older citizens. Leighley and Nagler (2013) find results for early adopting states that are similar to Hanmer (2009) but focus on percentage rather than percentage point changes. As a result, they present a much more optimistic view of the ability of EDR to benefit young people, which we view as largely a difference in perspective.

Several studies examine how election laws and residential mobility combine to influence turnout. Anyone who has moved knows it is a hassle. In the U.S., citizens confront a decentralized system where laws and procedures differ not just across states but often across local jurisdictions, along with the expectation that they take responsibility for learning the rules and how to navigate through them to register and then vote. This creates significant burdens, especially for young people who are more likely to be residentially mobile. A number of scholars have shown that registration requirements create a barrier to youth turnout, largely because

\footnotetext{
${ }^{4}$ Keele and Minozzi (2013) argue that large proportions of citizens from urban centers in the 1972 and 1976 Census data in key states limits comparisons that Hanmer (2009) makes, and suggests effect sizes might be even smaller. However, there is no evidence from the Census documentation or the data themselves to account for this claim for 1972. This could be a problem for 1976, but Hanmer (2009) did not use 1976 data in his analysis.
} 
young people are highly mobile (Ansolabehere, Hersh, and Shepsle 2012; Highton 2000; Squire, Wolfinger, and Glass 1987).

The National Voter Registration Act of 1993 (NVRA) was a wide ranging piece of legislation that required most states to actively seek to register eligible citizens through interactions with motor vehicle offices and public agencies. Failed implementation is a serious issue (e.g. Hess, Hanmer, and Nickerson 2015), but whatever the reason, the NVRA has yet to live up to expectations for higher and more equal turnout. Hanmer (2009) finds that some early adopters of registration through motor vehicle offices (which gave rise to the motor voter nickname) saw small increases in turnout but that the NVRA produced even smaller increases in turnout. Like EDR, the effects of motor voter appear largest for young people, though too small to reach the turnout levels of older Americans. Taken together, these results suggest that the costs of registration alone cannot account for unequal registration rates in the United States, though efforts to make registration easier and more equitable are still worthwhile. But as Hanmer (2009) emphasizes, these laws facilitate participation for those who are interested in participating in the first place, leaving open the question of how to get citizens interested enough to make use of easier registration rules.

Pre-registration is a relatively new reform that allows individuals to register prior to turning 18, even though they legally cannot vote until later. Holbein and Hillygus (2015) present a compelling case for why pre-registration can help increase youth participation. They argue that 16 year olds who register will feel like they are part of the system once they are pre-registered and that other institutional and social forces serve as support mechanisms. Using a difference-indifference approach they estimate the impact of pre-registration, finding positive though somewhat modest effects (often in the 2 to 5 percentage point range). As more states adopt pre- 
registration laws and groups seeking to engage new voters see the opportunity to engage with people at a younger age, scholars will have greater opportunities to identify the potential impact of pre-registration on the age gap in voting. One potential challenge lies in keeping preregistrants interested enough to bridge the gap between registration and voting, which could be as long as 2 years.

Online voter registration is another tool that should theoretically help close the gap between young and old voters. First introduced in Arizona in 2002, online registration is now available in 35 states and Washington, DC. ${ }^{5}$ While online registration should boost turnout simply because it is another method people can use on top of previously offered ones, it should disproportionately impact individuals who spend more time online. In 2008, 39 percent of 18-29 year-olds said they were online "almost constantly," compared to only 8 percent of those 65 and older. While recent literature finds that online registration only increases overall registration by a small amount with no increase in turnout (Gregorowicz and Hall 2016), other research finds that registration and turnout $d o$ increase when looking at younger Americans and especially those who have recently moved (Pellissier 2014). There is additional evidence that online registrants are disproportionately younger and more likely to vote after getting registered (Barreto et al. 2010).

Another new reform, automatic voter registration (AVR), represents a fundamental change in the philosophy of participation in the U.S. as it places the responsibility for registration on the government. Started in Oregon, AVR eliminates the two-step process of voting by using lists of eligible citizens from other government agencies to automatically register individuals to vote. This concept, however, has received little attention in the political behavior literature, in

\footnotetext{
${ }^{5}$ The Philadelphia Enquirer, “Online voter registration in Pa., three years in: More than 1 in 5 voters register online.
} 
large part due to a lack of available data. Preliminary analysis from Oregon, done by the Center for American Progress (CAP) shows that of approximately 272,000 people registered automatically, 98,000 of them voted in the 2016 presidential election; ${ }^{6}$ the $36 \%$ turnout rate among this group is substantially lower than the turnout rate among other registrants.

The low rate of turnout among automatic registrants strongly suggests greater efforts should be made to engage those who have been automatically registered. Since Oregon adopted this process, Rhode Island, Illinois, Alaska, Washington, Maryland, and New Jersey have all adopted similar measures. AVR is set to be implemented to some degree in 12 different states and the District of Columbia, meaning there will be greater opportunities to measure the impact of these reforms on youth participation. Importantly, the way in which the system is implemented varies and programs that are opt-in rather than opt-out are likely to be less successful for increasing registration and turnout.

None of the research cited above has investigated college students as a special subset of young people. Niemi and Hanmer $(2009,302)$ recognize that "college students are in the process of forming their identities and are doing so in a unique social and political environment." They argue that traditional theories do not always fit well with an attempt to understand political behavior of college students. However, they are not able to test directly the influence of registration laws on college students relative to non-college youth. That said, drawing on their work we offer some ideas here.

Many college students leave home for the first time to attend college. As noted above, moving is a disruptive process that brings with it a number of challenges. The easier voter registration is for those in a new place, with new responsibilities, but also new freedoms, the

\footnotetext{
${ }^{6}$ Center for American Progress, "Increasing Voter Participation in America," July 11, 2018.
} 
more likely it should be that they vote. That said, one of the more interesting findings from Niemi and Hanmer (2009) was that most college students prefer to register at their home address; though students were also strategic, such that those who attended school in a presidential battleground state were more likely to register in their college state. For students who want to vote at home, pre-registration, online registration, and AVR might be particularly effective. These policies help students get into the system and give them one less thing to worry about in their transition to college life; that said, students still have to either get back home to vote or cast an absentee ballot (more below). EDR provides a great deal of flexibility for college students. In addition to allowing students to register and vote with one stop, it gives those interested in voting in their college town more time to get interested and learn about the local contests. It also acts as a failsafe for those who miss the registration or absentee ballot windows at their non-college address to vote the full ballot on Election Day, provided they are willing to change their registration to their college address. One drawback is that those who wait to register on Election Day remain largely invisible during the campaigns since they are unlikely to be on any lists available to advocacy groups and political parties.

\section{Convenience Voting}

In addition to voter registration laws, convenience voting measures, aimed at making voting easier once one is registered, are also believed to be an important component of the puzzle of persistently low turnout. Berinsky (2005) provides a detailed examination of the overall effects of absentee balloting, early voting, vote-by-mail, and internet voting on voter turnout. These reforms, he argues, generate very modest increases in political participation overall. Furthermore, the increases to turnout are achieved by retaining citizens who already have a high propensity to vote, not by incorporating new and lower-propensity voters into the system. This 
suggests that young and less-engaged citizens are unlikely to be persuaded to vote by the lowering of voting costs alone. We seek here to examine each of the convenience voting reforms in turn, identify the impact each one has on turnout generally, and describe how each one should be expected to affect younger voters more specifically. As we show, there is evidence that many of these reforms could benefit youth participation disproportionately. Yet, as we note in a later section, these reforms will only provide a benefit if they are part of a larger effort to engage young voters and incorporate them into the political system.

The literature on convenience voting suggests that relaxed absentee ballot laws are unlikely to have huge effects in terms of decreasing the turnout gap between age cohorts (e.g. Karp and Banducci 2001). All states have some form of absentee ballot option. While some states have restrictions on who can take advantage of absentee voting, this should not matter for most young people who would need it. Unrestricted absentee voting is largely irrelevant for college students as those who attend school out of town have an excuse that would be valid under any absentee voting regime. That said, some college students have still asked for this type of convenience voting measure for local elections. For example, University of Maryland students have sought to get the College Park government to allow unrestricted absentee voting for local elections so that students can vote absentee rather than in person if they have class or work obligations on Election Day. Any effect of such reforms on turnout levels for college students, however, would be negligible, though such reforms in our view are still worthwhile, especially when unrestricted absentee voting is available for midterm and presidential elections. Unrestricted absentee voting provides an important avenue for people who physically cannot get to the polls to have the opportunity to vote, but we see little evidence it will boost youth turnout substantially. That said, we might well expect that deadlines for absentee ballot requests, the 
ability to make requests online, and the delivery of blank absentee ballots online (see Herrnson, Hanmer, and Koh 2018) to help young voters, and particularly college students.

Early voting, which is universally available in 21 states but is also available with some restrictions in other states, holds some promise for increasing voter turnout, though the literature suggests it does not help address unequal voting rates across the population (Neely and Richardson 2001; Stein 1998). Berinsky (2005) argues that early voting simply cannibalizes Election Day voting, making it a poor tool to address lagging and unequal turnout rates. Burden et al. (2014) take this a step further, arguing that early voting, when not coupled with the ability to register at the early voting site, actually decreases turnout because it eliminates some of the resources and social pressures that exist to vote on Election Day itself. Herron and Smith (2014), however, examine the effect of Florida's decision to reduce the number of early voting days from fourteen to eight and find that not only did this decision damage turnout, but it did so primarily among Democrats and minorities who had cast ballots in 2008 on the Sunday preceding the election. Ashok et al. (2016) find that early voting is used primarily by older voters, yet they also show that younger individuals who vote early do so very late in the early voting window. Any attempts to rectify the age gap in turnout through early voting reforms, then, likely have to focus on making sure that early voting is accessible the weekend prior to an election.

While the literature is, on the whole, mixed as to the impact of early voting on turnout rates, Fullmer (2015) demonstrates that much of the variation in the effect comes down to the concentration of early voting locations, not simply whether it is allowed legally. While a state may claim to have early voting sites, they may have early voting only on specific days or in locations that are convenient only for certain types of voters. Examining early voting through the concept of site availability (i.e. the number of early voting sites at the county level), Fullmer 
finds that site density is associated with significant positive effects on turnout. It is not clear from this analysis, however, how much increasing early voting sites will help younger voters relative to older cohorts. Compared to convenience voting measures like absentee balloting, the voter still has to turn up in person to vote, meaning the difference in cost between showing up on Election Day as opposed to an earlier day may not be particularly high.

In related research, Stein and Vonnahme (2008) examine the impact of vote centers on turnout. Unlike precinct voting stations, vote centers are fewer in number but are located in major population centers. They also do not require that voters be aware of their specific precinct polling location — any voter who lives in the area (such as a county) can obtain a ballot specific to the precinct in which they live. Stein and Vonnahme find that the existence of vote centers increases turnout, especially among infrequent voters and young voters. In a follow-up study, Stein and Vonnahme (2012) find that vote centers boosted turnout in Texas more than in Colorado. They suggest that part of this may have to do with the fact that one of the counties they study, Lubbock County, has a high concentration of college students. The extent to which this expectation is justified likely varies considerably based on how well students are integrated into the wider communities. That is, for those with internships or jobs that take them off campus, vote centers are particularly promising; but for students who do not regularly leave campus we expect no effect. While there is no way to directly test whether college students were driving Stein and Vonnahme's results, they suggest the need for greater research as they show the promise of this type of convenience voting measure for decreasing the age gap in voting. Vote-by-mail (VBM), another form of convenience voting, is available in 22 states, though only California, Colorado, Oregon, and Washington have moved to completely mailbased elections. The literature on convenience voting, however, largely views these reforms as 
helping to retain only higher-propensity voters. Berinsky, Burns, and Traugott (2001) find in Oregon that VBM increased turnout in the state, but did little to incorporate new voters into the system. Despite this finding, there is some reason to believe VBM may do more to increase turnout among younger voters than older voters. College students, for example, may not be able to make it back to their home polling station if they are no longer living in the area. While absentee voting helps address this issue, some college students may be unaware of this possibility. Voting via a mail-in ballot may help alleviate this issue because if they are already registered in the state, there is no need for them to fill out an application for an absentee ballot. A caveat of course, is that college students who register at their home address but attend school elsewhere will not have easy access to their ballot unless they have family who can provide it to them. Southwell and Burchett $(1997 ; 2000)$ find that while VBM does not improve the representativeness of the electorate, those who are most affected by the reform are those who had problems in the past getting to a polling location. Younger, more mobile individuals should likely fit into this category, though there is little research on how this reform affects them specifically.

On top of the costs of getting to the polling location (if necessary) there is the cost of knowing where one's polling location is actually located. Brady and McNulty (2011) show that the basic cost of knowing the location of a polling station disproportionately affects turnout among young people. This finding suggests that vote centers and absentee voting may provide young people an opportunity to vote that they otherwise would not have had. Not only are young people more mobile and, therefore, less likely to know where there polling location is, but when communities change polling locations, the effect is concentrated among younger and more mobile cohorts. 
A newer proposal intended to decrease the turnout gap between young and old focuses on lowering the voting age to 16 . Scholars, drawing from the literature that finds voting is a habitforming activity, argue that this tool holds promise and allows voter engagement campaigns to connect with citizens at a time when they might be more open to such efforts (Zeglovits and Aichholzer 2014; Zeglovits and Zandonella 2013). These scholars argue that voting is easier when informational costs are lower and individuals are operating in the community in which they grew up.

The logic for lowering the voting age to 16 is straight-forward. Because many Americans are leaving their childhood homes for the first time at age 18, they know little about the politics in their new community and may not be familiar with the rules governing elections in their new home or know where their polling location is located. By lowering the voting age to 16, they can vote in an election prior to leaving their communities, developing the voting habit at a time when they can more easily overcome the barriers to voting. This makes them more likely to continue voting in the future. This line of thinking is supported by the findings of Pacheco and Plutzer (2007), who show that individuals who drop out of high school vote at much lower rates, even if they returned later to earn their diploma. The authors theorize that the issue is not the attainment of education, but rather that life interruptions have a huge impact on the probability of voting. Lowering the voting age to 16 has the potential to generate voting habits in young Americans before many major life interruptions occur. Niemi and Hanmer (2010) make a similar argument in their research on turnout among college students. They find that the probability of voting among college students is higher for those who live closer to their childhood homes, suggesting that the informational costs of being newly away from home depress voting rates. 
While the internal logic of lowering the voting age is sound, there are factors that complicate this issue. Some studies (McAllister 2014; Wagner, Johann, and Kritzinger 2012) examine this question and do not find any impact of lowering the voting age on youth turnout. Yet the extant literature in this area by necessity relies on voting behavior outside the United States, since little data exist on 16-year-old voting habits in the American context. Groups like FairVote have been lobbying communities to lower the voting age with some success, giving researchers reason to suspect that there should be a greater availability of American test cases for future empirical study.

\section{Demobilization Efforts}

Despite the work of numerous scholars to identify the election reforms that would make voting the easiest, scholars must also contend with the political reality that some wish to make voting more difficult. As we previously noted, Florida chose to reduce the number of early voting days from fourteen to eight in what was largely seen as an attempt to depress Democratic turnout. Parties in power have an incentive to structure election laws to make it easier for their voters to get to the polls and harder for opposing partisans to vote. Using an event history analysis, Biggers and Hanmer (2017) find that the adoption of voter identification laws in the United States is more likely when Republicans take control of statehouses and governorships. Furthermore, this likelihood increases as the size of Black and Latino populations in the state grow, suggesting that much of the efforts of Republican legislatures to pass these sorts of laws are intended to keep minority groups, who vote overwhelmingly Democrat, from casting a ballot. While Republican legislators have claimed these measures are needed in order to fight voter fraud, there is little research suggesting voter fraud is a widespread problem in American elections. And as Biggers and Hanmer (2017) note, "if Republicans were mostly concerned 
about fraud, the new laws would aggressively target absentee ballots, which lend themselves to vote buying and intimidation." Voter identification measures, though, have not generally targeted these types of ballots.

A growing literature shows that voter identification laws disproportionately impact young and minority populations (Hajnal et al. 2017; Rogowski and Cohen 2012; Barreto, Nuno, and Sanchez 2009). Because many of these laws are new and more are being proposed every year, this is an area where there is no consensus on how to effectively teach young Americans about the requirements for registration and voting. Furthermore, there is little research to examine how voter identification laws affect youth participation in elections, though it seems likely that these measures should depress youth turnout. Young voters are more likely than middle-aged voters to lack identification, though this is also true for the elderly. Niemi, Hanmer, and Jackson (2009) analyze the laws related to college student registration and the ways state and local officials interpret these laws. They find not just wide variation in the restrictiveness of the laws but practices that violate the law by discriminating against college students. Though it is not the focus of their work, they discuss voter ID laws in their conclusion and predict these laws could pose especially large burdens for college students, particularly freshman or recent transfers who have less time to obtain documents needed to register.

\section{The Demobilizing Effect of Informational Costs}

In addition to the institutional barriers young people face in voting, there are also informational costs to voting. Just as being more mobile means young people are less aware of the voting rules where they live, they are also less familiar with the politics of their communities. Young people are poorer generally in resources, so the cost of familiarizing oneself with the 
nuances of politics is relatively larger for younger cohorts than it is for middle-aged and elderly groups (Plutzer 2002; Berinsky 2005).

One way young voters are supposed to be able to overcome the informational costs of voting is through campaigns. Elections create a media environment that should, theoretically, incorporate previously apathetic groups into the political process. Yet the media habits of younger Americans do not lend themselves to being reached (Wattenberg 2008) by civicallyminded organizations, and the campaigns themselves do not see much point in reaching out to young voters. While the campaigns can potentially get young people voting (Gimpel et al. 2003; Pacheco 2008 Rosenstone and Hansen 1993), campaigns focus their energy on those individuals they believe will not only support their candidate, but who are also more reliable voters. Individuals who are not on the voter rolls or those who have not voted in any previous election are often viewed as lost causes, not worth the investment by the campaign (Goldstein and Ridout 2002; Arceneaux and Nickerson 2009). While we see mobilization as an essential component of attempts to increase youth turnout, we recognize that changing the incentives for parties and candidates and/or increasing resources for citizen groups is easier said than done.

\section{Why Young People Do Not See Voting as Worth Their Effort}

A consistent finding throughout the literature on youth participation is that young people are not inherently disinclined toward politics, but rather that voting is not an activity young people find rewarding in the current political climate. In Martin Wattenberg's (2008) influential Is Voting for Young People? he identifies media consumption as a major factor that explains gaps in generational voting patterns. Wattenberg reasons that young people are turned off to politics. Civic duty, he contends, is no longer a major driver of behavior among the youngest 
groups of Americans, and if voting is not an obligation they need to keep as a citizen they will not cast a ballot. As a result, they are willing to let older cohorts set the agenda despite their differing priorities. The only solution, for him, is to make voting compulsory for all Americans.

Russell Dalton (2007) takes a slightly more optimistic view of young people in America. While he agrees that civic duty is no longer a deeply held social norm among young Americans, he reasons that young people have moved toward an engaged citizenry model. This argument is in line with Benenson, Brewer, and Thomas (2016), who find that young people are not apathetic and instead blame institutional factors for not cultivating politically engaged young people.

Dalton (2007) argues that voting is something people do out of a sense of duty, since the chance that anyone's vote is pivotal is astronomically low. Participating in more direct ways, such as joining a protest or contacting a member of Congress, however, is something younger people are actually doing at rates equal to or surpassing previous generations. Unlike Putnam's (2000) argument in Bowling Alone, Dalton argues that younger people do not lack social capital. According to Dalton, they are not less engaged politically than their predecessors, but instead of doing something out of some abstract sense of duty, they prefer to do something they find gratifying. Joining a protest movement, for example, is a more expressive political act than voting in an election. Schuessler (2000) describes expressive motivations as being driven by the desire to: 1) attach oneself to an outcome; and 2) attach oneself to the group of people who bring about that outcome. These activities should also provide those high in negative partisanship with higher levels of gratification, as they often center on voicing an opposition to a politician or a policy rather than support for an entire agenda. With the political activities described by Dalton (2007), it is clear that younger Americans are more interested in being a part of a movement, 
where kinship with similarly-minded individuals constitutes a tangible benefit one takes from participating.

The prior literature also describes young people as being politically engaged but largely estranged from establishment politics. Younger voters are generally low in external efficacy (Baumgartner and Morris 2006; Kahne and Westheimer 2006), so they see little reason to engage from within a system that is unlikely to change. Voting, unlike protesting, requires an individual to affirmatively support one side of the political divide. Protesting, however, becomes more popular in a political environment characterized by negative partisanship (Iyengar and Krupenkin 2018) and populist sentiment (Inglehart and Norris 2016). This suggests activist groups and political campaigns need to tailor messages to reach young people in a way that makes them feel like they are part of a movement. As we noted in our discussion of mobilization, this requires a shift in thinking by these groups that will not be easy to bring about.

\section{Recommendations for Youth Voting Research and Advocacy}

We have reviewed what political science knows about why some young people vote while many more do not. This review of the literature leads us to a puzzling conclusion. While turnout in the United States consistently lags behind other western countries, we frequently chalk that up to a difference in electoral rules or apathy that exists among young people toward politics. While those factors undoubtedly influence turnout, the extant research does not suggest that younger Americans are less politically motivated and only mixed evidence exists to suggest that they are more disillusioned or apathetic toward politics. As a result, we argue that removing the barriers that disproportionately affect young citizens will only yield significant results if they are coupled with efforts by states, partisan groups, and non-partisan groups to incorporate them into the electoral system. 
When it comes to reducing the institutional costs of voting, there is a large body of research that examines the aggregate effects of the most prominent reforms. Yet there is relatively little research on how these reforms influence young people specifically. Many of the registration and convenience voting measures show promise for boosting youth participation rates, yet the literature is underdeveloped and for a number of reforms, such as AVR, we don't yet have good data to examine their effects. Electoral reforms, such as EDR, in-person early voting, the availability of early voting centers, and vote by mail have all been shown to increase voting rates somewhat, but many states have pushed back against these reforms, making advocacy more important.

Certain reforms, we argue, should be enacted regardless of the impact it will have specifically on young people. This includes making it easier for people to find their polling location, learn of the registration cutoff in their state or eliminate it altogether, and to obtain the necessary identification to register. Yet we also believe more research is needed to discern precisely what kind of impact we should expect to see for young voters if more states adopted reforms to make voting easier, such as EDR or a system to pre-register all eligible voters. In particular, the idea of lowering the voting age to 16 holds a great deal of promise that is specific to youth turnout, but the dearth of data in the United States on this topic makes it difficult to say what the effect will be, if any. As communities begin to experiment more and more with this concept, political scientists should seek ways to determine what effect they are having.

We also do not yet know how early voting in particular should impact younger cohorts relative to older ones. Berinsky (2005) notes any effects are small, but Ashok et al. (2016) suggests that the final days of early voting matter more for younger people and Fullmer (2015) suggests that the density of early voting locations matter as well. This research suggests there 
may be ways of enacting early voting measures that target younger and less-engaged voters. Vote centers additionally appear to benefit younger cohorts the most, yet there has been little work that specifically examines the impact of these types of reforms specifically by age.

Instilling an interest in young people around politics and voting may be the most difficult place to make progress. There is no way to force families to raise their children to be civicallyminded citizens, and reforming the school system around civics classes proven to be effective for increasing engagement is difficult. Despite this, there remains a need for greater research on the types of community and school programs that have the biggest impact for individuals, both as young voters and later on in life. Charter schools, which provide more variation in the type of civic curriculum offered, provide an important opportunity for such research. While some research has been done in this area (see Gill et al. 2018), the field is far from reaching a consensus on a best practices approach.

Whereas cultivating engagement through socialization efforts is pragmatically difficult, we believe a promising path toward a more engaged generation of young citizens comes from outreach efforts. A convincing portion of the literature we have detailed suggests that young Americans do care about politics, but that voting is not their preferred way of participating. This provides hope that outreach efforts from both partisan and nonpartisan groups may be able to convince individuals that voting is worth their time. Among the biggest gaps in knowledge relate to how mobilization efforts can leverage the various institutional features that structure registration and voting. Here, the candidates, parties, advocacy groups, government, and other institutions, such as schools and colleges can all play a role. Precious few studies examine how messaging about these laws influences participation (but see Bennion and Nickerson 2011; Bryant et al. 2018; Herrnson, Hanmer, and Koh 2018). We believe there is tremendous room not 
just for new empirical insights but new theorizing about the messages content, frequency, mode of delivery, and source. Given that most high school graduates now attend college, the role colleges can play in this is increasingly important and should be part of this research agenda.

While states, political campaigns and activist groups have to make a concerted effort to reach out to young people, political science is uniquely positioned to systematically test which messages are most effective at registering and turning out younger voters. In a recent effort in 2016 to register eligible but unregistered (EBU) citizens in the State of Pennsylvania, the Secretary of State's Office sent out postcards to individuals identified by the Electronic Registration Information System (ERIC) as eligible but unregistered. While the effects of the postcards on EBU registration were modest (around a percentage point), the effects were roughly double for those aged 18-21, who were voting in their first presidential election (Bryant et al. 2018). Effects on turnout, while lower than effects on registration, were similarly higher for this group. These findings suggest that simply having states ask people to register will generate small increases in registration and turnout, and that the effects will be greatest among young people.

Because voting for many young people is an expressive act and likely motivated by negative partisanship, we also argue that the success of efforts to reach out to young citizens will ultimately come down to the ability of campaigns to channel the expressive motivations of young people into the act of voting. The messaging strategies political campaigns use will, therefore, become pivotal. Campaigns that can convince young people that voting is only one part of joining a broader movement will likely be more successful in connecting. While Rosenstone and Hansen (1993) suggest that social networks are the key to political mobilization, more research is needed to discern how campaigns can tap into younger networks, who are more likely than older cohorts to organize online. While there are countless groups seeking to organize individuals 
through social media platforms, there has been little scholarly work done to examine how these efforts might address the age gap in voter turnout. We believe these organization efforts, when coupled with the lowering of barriers that disproportionately impact younger and more mobile populations, might hold the greatest promise for bridging the participation gap between young and old. But research in this area has yet to scratch the surface.

We recognize that getting young people to vote is not going to be easy. Removing the barriers that dam up the registration and voting process is unlikely to unleash a torrent of new young voters; not unless those voters are first socialized to believe voting is a duty and mobilized by campaign professionals who can convince young people that something important is truly at stake. Developing new theories on how best to reach younger citizens and collecting new data to test those theories will be equally difficult. Despite the challenges, we hope scholars and advocacy groups alike find it worthwhile to pursue the avenues of research we outlined here. 


\section{Works Cited}

Ansolabehere, Stephen, Eitan Hersh, and Kenneth Shepsle. 2012. "Movers, Stayers, and Registration: Why Age Is Correlated with Registration in the U.S." Quarterly Journal of Political Science, 7(4): 333-63.

Arceneaux, Kevin and David W. Nickerson. 2009. "Who is Mobilized to Vote? A Re-Analysis of 11 Field Experiments.” American Journal of Political Science, 53: 1-16.

Ashok, Vivekinan, Daniel Feder, Mary McGrath, and Eitan Hersh. 2016. "The Dynamic Election: Patterns of Early Voting Across Time, State, Party, and Age." Election Law Journal, 15(2): 115-128.

Barreto, Matt, Bonnie Glaser, Karin MacDonald, Loren Collingwood, Francisco Pedraza, and Barry Bump. 2010. "Online Voter Registration (OLVR) Systems in Arizona and Washington: Evaluating Usage, Public Confidence and Implementation Processes." prepared for Washington Institute of the Study of Ethnicity and Race at the University of Washington, Seattle and the Election Administration Research Center at the University of California, Berkeley.

Barreto, Matt, Gary Segura and Nathan Woods. 2004. "The Effects of Overlapping MajorityMinority Districts on Latino Turnout.” American Political Science Review. 98 (1): 65-75.

Barreto, Matt A., Stephen A. Nuno, and Gabriel R. Sanchez. 2009. "The Disproportionate Impact of Voter-ID Requirements of the Electorate--New Evidence from Indiana." $P S$ : Political Science and Politics, 42(1): 111-116.

Baumgartner, Jody and Jonathan S. Morris. 2006. "The Daily Show Effect: Candidate Evaluations, Efficacy, and American Youth.” American Politics Research, 34(3): 341367.

Benenson, Jodi, Margaret Brower, and Nancy L. Thomas. 2016. "Political Citizenship: Whether and Why College Students Vote." in Why Don't Americans Vote? Causes and Consequences, eds. King, Bridgett A. and Kathleen Hale. ABC-CLIO.

Bennion, Elizabeth A., and David W. Nickerson. 2011. "The cost of convenience: An experiment showing e-mail outreach decreases voter registration.” Political Research Quarterly 64,(4): 858-869.

Berelson, Bernard R., Paul F. Lazarsfeld, and William N. McPhee. 1954. Voting: A Study of Opinion Formation in a Presidential Campaign. Chicago: University of Chicago Press.

Berinsky, Adam J. 2005. "The Perverse Consequences of Electoral Reform in the United States." American Politics Research, 33(4): 471-91. 
Berinsky, Adam J., Nancy Burns, and Michael W. Traugott. 2001. "Who Votes by Mail?: A Dynamic Model of Individual-Level Consequences of Voting-by-Mail Systems." Public Opinion Quarterly, 65(2): 178-197.

Bhatti, Yosef and Kasper M. Hansen. 2011. "The effect of generation and age on turnout to the European Parliament - How turnout will continue to decline in the future," Electoral Studies, 31(2): 262-272.

Biggers, Daniel R. and Michael Hanmer. 2017. "Understanding the Adoption of Voter Identification Laws in the American States." American Politics Research, 45(4): 560588.

Blais, Andre. 2000. To Vote of Not to Vote: The Merits and Limits of Rational Choice Theory. Pittsburgh, PA: University of Pittsburgh Press.

Brady, Henry, and John McNulty. 2011. "Turning Out to Vote: The Costs of Finding and Getting to the Polling Place.” American Political Science Review, 105(1): 115-34.

Bryant, Lisa A., Michael J. Hanmer, Jared A. McDonald, and Alauna Safarpour. 2018. “A Field Experiment to Examine States' Efforts to Increase Registration \& Turnout.” Working paper.

Brians, Craig L. and Bernard Grofman. 1999. "When Registration Barriers Fall, Who Votes? An Empirical Test of a Rational Choice Model.” Public Choice, 99: 161-176.

Burden, Barry C., David T. Canon, Kenneth R. Mayer, and Donald P. Moynihan. 2013. "Election Laws, Mobilization, and Turnout: The Unanticipated Consequences of Election Reform." American Journal of Political Science, 58(1): 95-109.

Campbell, Angus, Philip Converse, Warren Miller, and Donald Stokes. 1960. The American Voter. New York: Wiley.

Campbell, David E. 2006. Why We Vote: How Schools and Communities Shape Our Civic Life. Princeton, NJ: Princeton University Press.

Campbell, David E. and Richard G. Niemi. 2016. "Testing Civics: State-Level Civic Education Requirements and Political Knowledge.” American Political Science Review, 110(3): 495-511.

Dalton, Russell. 2007. The Good Citizen: How a Younger Generation is Reshaping American Politics. CQ Press.

Dee, Thomas S. 2004. “Are There Civic Returns to Education?” Journal of Public Economics, 88: $1697-1720$.

Downs, Anthony. 1957. An Economic Theory of Democracy. New York: Harper \& Row. 
Fullmer, Elliott B. 2015. "The Site Gap: Racial Inequalities in Early Voting Access.” American Politics Research, 43(2): 283-303.

Gerber, Alan. S., Donald P. Green, and Ron Shachar. 2003. "Voting may be habit-forming: Evidence from a randomized field experiment." American Journal of Political Science, 47(3), 540-550.

Giersch, Jason and Christopher Dong. 2017. "Required civics courses, civics exams, and voter turnout.” The Social Science Journal, online October 2017.

Gilens, Martin. 2012. Affluence and Influence: Economic Inequality and Political Power in America. Princeton, NJ: Princeton, NJ: University Press.

Gill, Brian; Charles Tilley; Emilyn Whitesell; Mariel Finucane; Liz Potamites; and Sean Corcoran. 2018. "The Impact of Democracy Prep Public Schools on Civic Participation." Report by Mathematica Policy Research.

Gimpel, Jim, J. Celeste Lay, and Jason E. Schuknecht. 2003. "Cultivating Democracy: Civic environments and political socialization in America." The Brookings Institution, Washington, DC.

Goldstein, Kenneth M. and Travis N. Ridout. 2002. "The Politics of Participation: Mobilization and Turnout over Time.” Political Behavior, 24: 3-29.

Gosnell, Harold F. 1927. Getting-Out-The-Vote: An Experiment in the Stimulation of Voting. Chicago: University of Chicago Press.

Gregorowicz, Krysha and Thad Hall. 2016. "Digitizing Democracy: Online Voter Registration." In Bridgett King and Kathleen Hale (Eds.), Why Don't Americans Vote? Causes and Consequences (pp. 22-29). ABC-CLIO.

Hajnal, Zoltan, Nazita Lajevardi, and Lindsay Nielson. 2017. "Voter Identification Laws and the Suppression of Minority Votes.” Journal of Politics, 79(2): 363-379.

Hanmer, Michael J. 2009. Discount Voting: Voter Registration Reforms and Their Effects. New York: Cambridge University Press.

Haste, Helen. 2010. "Citizenship education: A critical look at a contested field." In L. R. Sherrod, J. Torney-Purta, \& C. Flanagan (Eds.), Handbook of research on civic engagement in youth (pp. 161-188). Hoboken, NJ: John Wiley and Sons.

Herrnson, Paul S., Michael Hanmer, and Ho Youn Koh. 2018. "Mobilization Around New Convenience Voting Methods: A Field Experiment to Encourage Voting by Mail with a Downloadable Ballot and Early Voting." Political Behavior. online June 20, 2018. 
Herron, Michael C. and Daniel A. Smith. 2014. "Race, Party, and the Consequences of Restricting Early Voting in Florida in the 2012 General Election." Political Research Quarterly, 67(3): 646-665.

Hess, Douglas R., Michael Hanmer, and David Nickerson. 2015. "Encouraging Local Compliance with Federal Civil Rights Laws: Field Experiments with the National Voter Registration Act." Public Administration Review, 76:165-174, 2016.

Highton, Benjamin. 2000. "Residential Mobility, Community Mobility, and Electoral Participation.” Political Behavior, 22(2): 109-120.

Highton, Benjamin. 1997. "Easy Registration and Voter Turnout.” Journal of Politics, 59: 565575.

Holbein, John B. and D. Sunshine Hillygus. 2015. "Making Young Voters: The Impact of Preregistration on Youth Turnout." American Journal of Political Science, 60(2): 364382.

Huang, Chi and Todd Shields. 2000. "Interpretation of Interaction Effects in Logit and Probit Analyses: Reconsidering the Relationship between Registration Laws, Education, and Voter Turnout." American Politics Quarterly, 28: 80-95.

Inglehart, Ronald F. and Pippa Norris. 2016. "Trump, Brexit, and the Rise of Populism: Economic Have-Nots and Cultural Backlash," Harvard Kennedy School Faculty Research Working Paper 26.

Iyengar, Shanto and Masha Krupenkin. 2018. "The Strengthening of Partisan Affect." Political Psychology 39(S1): 201-218.

Jennings, M. Kent, and Richard G. Niemi. 1974. Political character of adolescence: The influence of families and schools. Princeton, NJ: Princeton University Press.

Kahne, Joseph and Joel Westheimer. 2006. “The Limits of Political Efficacy: Educating Citizens for a Democratic Society.” PS: Political Science and Politics, 39(2): 289-296.

Karp, Jeffrey. A. and Susan A. Banducci. 2000. "Going postal: How all-mail elections influence turnout." Political Behavior, 22, 223-239.

Keele, Luke and William Minozzi. 2013. "How Much is Minnesota Like Wisconsin? Assumptions and Counterfactuals in Causal Inference with Observational Data." Political Analysis, 21(2): 193-216.

Knack, Stephen and James White. 1998. "Did Motor Voter Programs Help the Democrats?" American Politics Quarterly, 26: 344-365. 
Leighley, Jan E., and Nagler, Jonathan. 2013. Who votes now? Demographics, issues, inequality, and turnout in the United States. Princeton: Princeton University Press

Lijphart, Arend. 1997. "Unequal Participation: Democracy's Unreseolved Dilemma." Presidential Address, American Political Science Association, 1996. American Political Science Review, 91: 1-14

Mansbridge, Jane. 1999. "Should Blacks Represent Blacks and Women Represent Women? A Contingent 'Yes."' Journal of Politics, 61(3): 628-657.

McAllister, Ian. 2014. "The politics of lowering the voting age in Australia: Evaluating the evidence," Australian Journal of Political Science, 49(1): 68-83.

Mendelberg, Tali, Christopher F. Karpowitz, and Nicholas Goedert. 2013. "Does Descriptive Representation Facilitate Women's Distinctive Voice? How Gender Composition and Decision Rules Affect Deliberation.” American Journal of Political Science, 58(2): 261306.

Michelson, Melissa R. 2006. "Mobilizing the Latino Youth Vote: Some Experimental Results." Social Science Quarterly, 87:1188-1206.

Milligan, Kevin, Enrico Moretti, and Philip Oreopoulos. 2004. "Does Education Improve Citizenship? Evidence from the United States and the United Kingdom." Journal of Public Economics, 88(9-10): 1667-1695.

Mitchell, Glen E. and Christopher Wlezien. 1995. "The Impact of Legal Constraints on Voter Registration, Turnout, and the Composition of the American Electorate." Political Behavior, 17: 179-202.

Nagler, Jonathan. 1991. "The Effect of Registration Laws and Education on U.S. Voter Turnout.” American Political Science Review, 85: 1393-1405.

Nagler, Jonathan. 1994. "Scobit: An Alternative Estimator to Logit and Probit." American Journal of Political Science, 38: 230-255.

Neely, Grant W. and Lilliard E. Richardson, Jr. 2001. "Who is early voting? An individual level examination." The Social Science Journal, 38: 381-392.

Niemi, Richard G. and Michael Hanmer. 2010. "Voter Turnout Among College Students: New Data and a Rethinking of Traditional Theories." Social Science Quarterly, 91: 301-323.

Niemi, Richard G., Michael Hanmer, and Thomas Jackson. 2010 "Where Can and Should College Students Vote?: A Legal and Empirical Perspective." Election Law Journal, 8: 327-348. 
Niemi, Richard G., and Jane Junn. 2005. Civic Education: What Makes Students Learn. New Haven, CT: Yale University Press.

Pacheco, Julianna Sandell. 2008. "Political Socialization in Context: The Effect of Political Competition on Youth Voter Turnout." Political Behavior, 30:415-436.

Pacheco, Julianna Sandell and Eric Plutzer. 2007. "Stay in School, Don't Become a Parent: Teen Life Transitions and Cumulative Disadvantages for Voter Turnout." American Politics Research, 35(1): 32-56.

Pellissier, Allyson. "In Line or Online? American Voter Registration in the Digital Era." Working Paper from Caltech/MIT Voting Technology Project.

Pitkin, Hanna F. 1967. The Concept of Representation. Berkeley: University of California Press.

Powell, G. Bingham Jr. 1986. "American Voter Turnout in Comparative Perspective.” American Political Science Review, 80(1): 17-43.

Plutzer, Eric. 2002. "Becoming a Habitual Voter: Inertia, Resources, and Growth in Young Adulthood." American Political Science Review, 96(1): 41-56.

Putnam, Robert D. 1995. "Tuning in, Tuning Out: The Strange Disappearance of Social Capital in America." PS: Political Science and Politics, 28 (4): 664-83.

Reingold, Beth and Jessica Harrell. 2009. "The Impact of Descriptive Representation on Women's Political Engagement: Does Party Matter?” Political Research Quarterly, 63(2): 280-294.

Riker, William H., and Peter C. Ordeshook. 1968. "A Theory of the Calculus of Voting." American Political Science Review, 62(1): 25-42.

Rosenstone, Steven and John Mark Hansen. 1993. Mobilization, Participation, and Democracy in America. New York: Macmillan Publishing Co.

Rouse, Stella. 2013. Latinos in the Legislative Process: Interests and Influence. New York: Cambridge University Press.

Schuessler, Alexander A. 2000. A Logic of Expressive Choice. Princeton: Princeton University Press.

Sondheimer, Rachel M. and Donald P. Green. 2010. "Using Experiments to Estimate the Effects of Education on Voter Turnout." American Journal of Political Science, 54(1): 174-189.

Southwell, Priscilla, and Justin Burchett. 1997. "Survey of vote-by-mail senate election in the state of Oregon." PS: Political Science and Politics, 30: 53-57. 
Southwell, Priscilla, and Justin Burchett. 2000. "Does changing the rules change the players? The effect of all-mail elections on the composition of the electorate." Social Science Quarterly, 81: 837-845.

Squire, Peverill, Raymond E. Wolfinger, and David P. Glass. 1987. "Residential Mobility and Voter Turnout." American Political Science Review, 81: 45-65.

Stein, Robert M. 1998. "Early voting.” Public Opinion Quarterly, 62: 57-69.

Robert M. Stein and Greg Vonnahme. 2012. "Effect of Election Day Vote Centers on Voter Participation," Election Law Journal, 11(3): 291-301.

Robert M. Stein and Greg Vonnahme. 2008. "Engaging the Unengaged Voter: Vote Centers and Voter Turnout," The Journal of Politics, 70(2): 487-497.

Rogowski, Jon C. and Cathy J. Cohen. 2012. "Turning Back the Clock on Voting Rights: The Impact of New Photo Identification Requirements on Young People of Color.' Report prepared for the Black Youth Project

Rosenstone, Steven J., and John Mark Hansen, 1993. Mobilization, Participation, and Democracy in America. Macmillan.

Tate, Katherine. 2003. Black Faces in the Mirror: African Americans and Their Representatives in the U.S. Congress. Princeton: Princeton University Press.

Teixeira, Ruy A. 1992. The Disappearing American Voter. Washington, DC: Brookings Institution Press.

Tripodo, Andrew and Robert Pondiscio. 2017. "Seizing the Civic Education Moment." Educational Leadership, 75(3): 20-25.

Verba, Sidney, Kay L. Schlozman, and Henry E. Verba. 1995. Voice and Equality: Civic Voluntarism in American Politics. Cambridge, MA: Harvard University Press.

Wagner, Markus, David Johann, and Sylvia Kritzinger. 2012. "Voting at 16: Turnout and the quality of vote choice." Electoral Studies, 31(2): 372-383.

Wattenberg, Martin P. 2008. Is Voting for Young People. New York: Routledge Press.

Wolfinger, Raymond E. and Steven J. Rosenstone. 1980. Who Votes? New Haven: Yale University Press.

Zeglovits, Eva and Julian Aichholzer. 2014. "Are People More Inclined to Vote at 16 than at 18 ? Evidence for the First-Time Voting Boost Among 16- to 25-YearOlds in Austria," Journal of Elections, Public Opinion and Parties, 24(3): 351-361. 
Zeglovits, Eva and Martina Zandonella. 2013. "Political interest of adolescents before and after lowering the voting age: the case of Austria," Journal of Youth Studies, 16(8): 1084-1104 